\title{
Profile Characteristics of the Registered Farmers of Interactive Information and Dissemination System in Telangana
}

\author{
B. Soumya, B. Savitha* and I. Sreenivasa Rao \\ Extension Education Institute, University Head, Rajendranagar, Hyderabad, India \\ *Corresponding author
}

\section{A B S T R A C T}

\begin{tabular}{l} 
Ke y w o r d s \\
$\begin{array}{l}\text { IIDS, Agro } \\
\text { advisories, } \\
\text { Determinants, } \\
\text { Adoption, ICT }\end{array}$ \\
\hline Article Info \\
$\begin{array}{l}\text { Accepted: } \\
\text { 24 August } 2020 \\
\text { Available Online: } \\
\text { 10 September } 2020\end{array}$ \\
\hline
\end{tabular}

The increasing penetration of ICT'S in agriculture scenario makes an opportunity to disseminate the useful information more widely among the farming community. These ICT's are helping to meet the information needs of farmer. The present study was conducted with 120 farmers who got registered under Interactive Information and Dissemination System (IIDS) in two districts i.e. Nalgonda and Khammam Districts of Telangana State, India. The farmers were selected by random sampling method. The study used ex-post facto research design. The results indicated that, majority of farmers $(56.67 \%)$ were under middle with intermediate level of education followed by high schooling $(25.00 \%)$, majority $(53.34 \%)$ had medium farming experience with small farm size (34.17\%), medium level of Information acquisition behaviour, medium level of ICT use. The majority (63.33\%) of the respondents had high innovativeness and 66.67 per cent of respondents expressed that they were visiting KVK's specially to get agriculture information.

\section{Introduction}

Information and

Communication Technologies (ICT's) are facilitating faster sharing of information and innovations and acting as a key agent for changing agrarian situation and farmers lives by improving access to information and sharing of knowledge. The information and communication technologies like radio, TV, newspaper, telephone and magazines are playing a major role in agricultural development since early decades. Now the modern Information Communication Technologies (ICTs) as mobiles and computers have created an information revolution. In the 21 st century, cost effective and efficient communication technologies are required to take lead in changing agricultural scenario.

The government has a huge research and development infrastructure in the form of institutions such as the State Agricultural Universities (SAUs) and Krishi Vigyan Kendras (KVKs). The role of this set-up in research and extension activity is of great importance. The use of Interactive Information and Dissemination System (IIDS) in extension system of Krishi Vigyan Kendra's is new ICT initiatives to meet the 
information needs and expectations of the farmers.

The project was sanctioned by the Indian Council of Agricultural Research (ICAR), Government of India, New Delhi under National Agricultural Innovation Project (NAIP), as a Consortium Leader with PJTSAU (formerly ANGRAU), Hyderabad, National Institute of Rural Development (NIRD), Hyderabad and Mudra Institute of Communication, Ahmedabad (MICA) as the partners. It has developed as an alternative ICT model to meet the information needs of Indian farmers. It was successfully pilot tested in Andhra Pradesh and Telangana states of India. Subject areas of IIDS are Agronomy, Plant protection, Horticulture, Animal science, Home science, Dairy, etc. Advantages of IIDS are farmers can get free information, location specific information delivery, provide information in local language and cost effective. So keeping these points in mind the study was mainly focused to reveal the extent adoption of agro advisories disseminated through IIDS and relationship between the profile and extent of adoption by the respondents of Nalgonda and Khammam districts. Keeping this view an attempt was made to study the profile characteristics of registered farmers and to assess their association with the extent of adoption of agro advisory services of

\section{Materials and Methods}

Ex-post facto research design was adopted for the study, since the variables chosen for the study have already occurred.

Ex-post facto research is a systematic empirical enquiry, in which the researcher does not have direct control on influencing (independent) variables because their manifestations have already occurred. Influence about relations among variables are made without direct intervention, but from concomitant variation of independent (influencing) and dependent (consequent) variables. Profile of the respondent farmers was studied with the help of structured interview schedule and frequency percentages and correlation coefficient methods were adopted for analysis of the data. The state of Telangana was selected purposively because IIDS project was implemented first time in Telangana state and erstwhile Andra Pradesh and the investigator hails from the same state. A total of 120 IIDS registered farmers at the rate of sixty from each district were selected by adopting simple random sampling technique.

\section{Results and Discussion}

\section{Profile characteristics of registered farmers of AKPS}

Age

From the table 1 and it was found that, majority of the respondents were categorized into middle age group $(56.67 \%)$, followed by young (30.83\%) and old (12.50\%) age group.

It could be inferred from the table that, majority of farmers $(56.67 \%)$ were under middle age category followed by young (30.83\%) and old (12.50\%) age category. The probable reason for majority of the farmers being under middle age category might be that, middle aged people are enthusiastic to use mobile phones pertaining to agriculture and allied activities.

The other reason for above result might be due to the fact that old age farmers still not habituated to use the ICT tools. The young people are inclining towards migrating to towns and cities for business and other high income generating activities. This finding is supported by Kakade and Kolar (2014).

\section{Education}


About education of the respondents it could be observed from the table 1 that, 25.83 per cent of the respondents had intermediate level of education followed by high schooling (25.00\%), middle school (18.33\%), undergraduation (14.17), primary school $(9.17 \%)$, post-graduation $(5.00 \%)$, illiterate $(1.66 \%)$ and functionally literate $(0.83 \%)$ respectively.

It could be inferred from the table that, education plays a vital role in moulding and bringing desirable changes and this might be due to that respondents have realization of importance of formal education in the present situation. As they had education, they were able to gather additional information on agro advisories disseminated through AKPS. This finding is in confirmative with the findings of Eladagi (2014).

\section{Annual Income}

It could be observed from table 1 that, 48.34 per cent of the respondents had medium annual income followed by low $(32.00 \%)$ and high $(24.99 \%)$. It could be inferred that majority of the respondents had medium annual income. This might be due to the fact that majority of respondents were small farmers and both the selected districts were with enough resources for doing farming. The result was in conformity with the findings of Patil (2016).

\section{Farming experience}

As it is seen from the table 1, majority $(53.34 \%)$ of the respondents had medium farming experience followed by low $(33.34 \%)$ and high $(13.32 \%)$ farming experience. It could be inferred that majority of the respondents had medium farming experience and it might be due to the fact that, majority of the respondents in the present study belonged to medium to young age categories.
The result was in conformity with the findings of Eladagi (2014).

\section{Farm size}

As it is seen from the table that, 34.17 per cent of the respondents had small farm size followed by semi medium (33.33\%), marginal (16.67\%), medium (13.33\%) and large $(2.5 \%)$ farm size category.

This might be due to the fragmentation of ancestral land holding from generation to generation leading to sub division of land to smaller size of land holding. The result was in conformity with the findings of Ansari and Pandey (2013).

\section{Socio-political participation}

The findings regarding socio-political participation of the respondents were tabulated below. Results in the table 1 indicated that, majority $(60.83 \%)$ of the respondents fall under medium level of sociopolitical participation followed by high $(28.33 \%)$ and low (10.83\%) socio-political participation categories. It could be inferred that, medium level of socio-political participation of majority of farmers were due to their participation in extension activities they could able to know the importance of organizations involving them to take responsibilities in community activities, interaction and social exchange, thereby making them to participate actively in socio and political issues of the village, most of the farmers felt village organization as an important service provider and social contact oriented hub due to the existence of wide network of linkages with several agencies and cooperatives might be the reason for the above trend. The result was in conformity with the findings of Yadev (2013). 
Table.1 Distribution of respondents based on the selected profile characteristics

\begin{tabular}{|c|c|c|c|}
\hline Variable & Categories & Frequency $(\mathrm{N}=120)$ & Percentage \\
\hline \multirow{3}{*}{ Age } & Young age ( up to 34 ) & 37 & 30.83 \\
\hline & Middle age (34-55) & 68 & 56.67 \\
\hline & Old age $>55$ & 15 & 12.50 \\
\hline \multirow[t]{8}{*}{ Education } & Illiterate & 2 & 1.66 \\
\hline & Functionally literate & 1 & 0.83 \\
\hline & Primary school & 11 & 9.17 \\
\hline & Middle school & 22 & 18.33 \\
\hline & High school & 30 & 25.00 \\
\hline & Intermediate & 31 & 25.83 \\
\hline & Under graduation & 17 & 14.17 \\
\hline & Post graduation & 6 & 5.00 \\
\hline \multirow[t]{3}{*}{ Annual Income } & Low annual income & 32 & 26.67 \\
\hline & Medium annual income & 58 & 48.34 \\
\hline & High annual income & 30 & 24.99 \\
\hline \multirow[t]{3}{*}{ Farming Experience } & Low farming experience & 40 & 33.34 \\
\hline & Medium farming experience & 64 & 53.34 \\
\hline & High farming experience & 16 & 13.32 \\
\hline \multirow[t]{5}{*}{ Farm size } & Marginal (0.1-1.0 ha) & 20 & 16.67 \\
\hline & Small (1.1-2.0 ha) & 41 & 34.17 \\
\hline & Semi medium (2.1-4.0 ha) & 39 & 33.33 \\
\hline & Medium (4.1-10.0 ha) & 16 & 13.33 \\
\hline & Large (10 ha and above) & 3 & 2.50 \\
\hline \multirow[t]{3}{*}{ Socio political participation } & $\begin{array}{l}\text { Low socio political } \\
\text { participation }\end{array}$ & 13 & 10.83 \\
\hline & $\begin{array}{l}\text { Medium socio political } \\
\text { participation }\end{array}$ & 73 & 60.83 \\
\hline & $\begin{array}{l}\text { High socio political } \\
\text { participation }\end{array}$ & 34 & 28.33 \\
\hline \multirow[t]{3}{*}{$\begin{array}{l}\text { Information } \\
\text { Behaviour }\end{array}$} & $\begin{array}{l}\text { Low information acquisition } \\
\text { behaviour }\end{array}$ & 25 & 20.83 \\
\hline & $\begin{array}{l}\text { Medium information acquisition } \\
\text { behaviour }\end{array}$ & 68 & 56.67 \\
\hline & $\begin{array}{l}\text { High information acquisition } \\
\text { behaviour }\end{array}$ & 27 & 22.50 \\
\hline \multirow[t]{3}{*}{ Use of ICT tools } & Low & 15 & 12.50 \\
\hline & Medium & 60 & 50.00 \\
\hline & High & 45 & 37.50 \\
\hline \multirow[t]{3}{*}{ Innovativeness } & Low innovativeness & 7 & 5.83 \\
\hline & Medium innovativeness & 37 & 30.84 \\
\hline & High innovativeness & 76 & 63.33 \\
\hline \multicolumn{4}{|l|}{ Access to KVK } \\
\hline \multirow[t]{3}{*}{ Distance from village to $\mathrm{KVK}$} & Below $20 \mathrm{~km}$ & 38 & 31.67 \\
\hline & $20-40 \mathrm{~km}$ & 42 & 35.00 \\
\hline & $40-60 \mathrm{~km}$ & 40 & 33.33 \\
\hline
\end{tabular}




\begin{tabular}{|c|c|c|c|}
\hline \multirow[t]{3}{*}{ Access to information at KVK } & Very easy & 54 & 45.00 \\
\hline & Easy & 48 & 40.00 \\
\hline & Difficult & 18 & 15.00 \\
\hline \multirow[t]{3}{*}{ Scientists availability at KVK } & Always & 56 & 46.67 \\
\hline & Sometimes & 40 & 33.33 \\
\hline & Never & 24 & 20.00 \\
\hline \multirow[t]{3}{*}{ Frequency of visit to KVK } & Daily once & 36 & 30.00 \\
\hline & Weekly once & 52 & 43.33 \\
\hline & Monthly once & 32 & 26.67 \\
\hline \multirow[t]{3}{*}{ Purpose of visit to KVK } & Agriculture information & 80 & 66.67 \\
\hline & Information regarding training & 25 & 20.83 \\
\hline & Allied sector information & 15 & 12.5 \\
\hline \multirow{3}{*}{$\begin{array}{l}\text { Whether the information } \\
\text { addressing immediate needs } \\
\text { or not }\end{array}$} & Always & 58 & 48.33 \\
\hline & Sometimes & 35 & 29.17 \\
\hline & Never & 27 & 22.50 \\
\hline
\end{tabular}

\section{Information acquisition behaviour}

The findings regarding information acquisition behaviour of the respondents were tabulated below. Results from the table indicate that, majority $(56.67 \%)$ of the respondents fall under medium level of information acquisition behaviour followed by high $(22.50 \%)$ and low $(20.83 \%)$. It could be inferred that, medium level of Information acquisition behaviour of majority of respondents as due to the fact that, amongst modern sources, they acquired information daily basis from T.V. \& mobile applications, where as in traditional sources daily they were acquiring information from farm literature sources, relatives and friends, neighbours and input dealers. Amongst the formal sources, weekly once they were getting information from A.E.O's, A.O.'s and others. This finding is in supportive with Patil (2016).

\section{Use of ICT tools}

It was observed from the table 1 that, majority of the respondents $(50.00 \%)$ belonged to medium category followed by high $(37.50 \%)$ and low $(12.50 \%)$ category. It could be inferred that the medium usage of ICT tools among the respondents may be due to awareness on importance of ICTs in agricultural extension system and high purchase cost of electronic gadgets and majority of the respondents were with medium annual income might be also the reasons for this trend. Although, respondents were not using computer/laptop at personal level but they are using mobiles/smart phones with internet facility. This trend is showing the very good possibility of capacity building of farmers through ICT tools at their ease level, time and pace to speed up the technology transfer skills. The result was in conformity with the findings of Madan (2017).

\section{Innovativeness}

The findings regarding innovativeness of the respondents were presented in the table 1 . The data revealed that majority $(63.33 \%)$ of the respondents had high innovativeness followed by medium $(30.84 \%)$ and low $(5.83 \%)$ levels of innovativeness. It could be inferred that, majority of the respondents had high innovativeness. The reason might be majority of the respondents were using mobile for accessing information to adopt innovative methods in farming. The result was in conformity with the findings of Samatha (2011) and Karuppasamy (2013). 


\section{Access to KVK}

The data revealed that 35.00 per cent of the respondents villages were within 20-40 kilometres away from KVK. 45.00 per cent of the respondents were getting information easily from KVK and 46.67 per cent of the respondents expressed that the scientists were always availability at KVK. With respect to frequency of visit to KVKs, 43.33 per cent of the respondents were visiting KVK's at least once in a week. 66.67 per cent of respondents expressed that they were visiting KVK's specially to get agriculture information and queries of the farmers were provided with solutions $(48.33 \%)$.

In conclusion a developing country like India where the introduction of ICT tools for agricultural extension is till new, challenges have been many both in the extension mechanism and the farmers or the end users side. Proper understanding of its use, its credibility and the access are the major bottlenecks along many others. The findings presented in the preceding section lead to conclusion that farmers registered in IIDS were belonged to middle age, with medium annual income, farming experience, socio political participation, information acquisition behavior, use of ICT tool and innovativeness.

\section{References}

Ansari, M.A. and Pande, N. 2013. Assessing the potential and use of mobile phones in agriculture. Karnataka Journal of Agriculture Sciences. 26(3): 388-392.

Eladagi, P. S. 2014. A study on farmers perception and utility of mobile e- extension services in agriculture. M.Sc (Ag.) Thesis. University of Agricultural Sciences, Raichur, Karnataka, India.

Kakade, O. and Kolar, T.N.S. 2014. Usage of mobile communication for sustainable agricultural development in Karnataka, India. Journal of Media and Social Development. 2(3): 19-37.

Karuppasamy, A. 2013. Effectiveness of paddy expert system in terms of knowledge gain, skill acquisition and symbolic adoption behaviour among the paddy growers - A experimental research. M.Sc. (Ag.) Thesis. Tamil Nadu Agricultural University, Coimbatore.

Madan mohan reddy, K. 2017. Impact of mobile phone based agro-advisory services on cotton farmers. Ph.D Thesis. PJTSAU, Hyderabad.

Patil, K.V. 2016. Utilization pattern of Kisan Mobile Advisory Services by the farmers of Banaskantha District. M.Sc. (Ag.) Thesis. Sardarkrushi Danttiwada Agricultural University.

Samatha, J. 2011. Extent of use of information and communication technologies (ICTs) in selected crops by the farmers of Guntur district in Andhra Pradesh. M.Sc. (Ag.) Thesis. Acharya N. G. Ranga Agricultural University, Hyderabad.

Yadev, P.C., Kunchala, K.D and Arun, P. 2013. Attitude of farmers towards Kisan Call Centre. National Seminar on Futuristic Agricultural Extension for Livelihood Improvement and Sustainable Development. Compendium. 391.

\section{How to cite this article:}

Soumya, B., B. Savitha and Sreenivasa Rao, I. 2020. Profile Characteristics of the Registered Farmers of Interactive Information and Dissemination System in Telangana. Int.J.Curr.Microbiol.App.Sci. 9(09): 3277-3282. doi: https://doi.org/10.20546/ijcmas.2020.909.406 